\title{
Cyclical Behaviour of Residential Markets
}

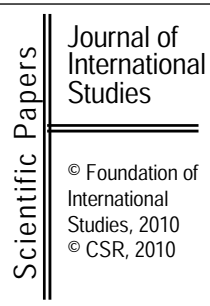

Dr Radosław Trojanek

Department of Investment and Real Estate

Faculty of Management

Poznan University of Economics

r.trojanek@ue.poznan.pl

\begin{abstract}
Each market, same as the whole economy, is subject to business cycles. This rule can be applied also to real estate market [Gawron, 2006, p.69]. This paper presents three main topics: idea of business cycle on real estate market, survey of residential price cycles in chosen OECD countries and an analysis of dwelling's price cycles in Poznań in the period 1996 - II Q. 2009.
\end{abstract}

Submitted: April, 2010 $1^{\text {st }}$ revision: May, 2010 Accepted: June, 2010

Keywords: business cycles, estate market, Poland.

JEL classification: E32, R33, P2.

\section{Idea of real estate cycles}

In time series of variables describing real estate market it's possible to find a trend, as well as seasonal, accidental and cyclic fluctuations. These variables are demand, supply or prices on real estate market ${ }^{1}$. With reference to prices on real estate market we can say about a trend (in most cases these prices are of positive trend, except for Germany and Switzerland where in 1975-2005 real market prices were of decreasing trend.), seasonal fluctuations (an increase of transactions number during summer holidays), accidental fluctuations (decrease of flats prices in flooded areas in Wrocław in 1997) and cyclic fluctuations resulted from economic factors having an influence on behaviour of this market participants.

In foreign real estate market literature we can find various methods of such trends definitions. These definitions mostly refer directly to terms of business cycles in the economy [Key, Macgregor, Nanthakumaran, Zarkesh, 1994, p.9].

Similar definition was proposed by A. Baum [Baum, 2001], who describes real estate business cycle as a tendency of demand, supply, prices and rates of return on property to fluctuations around their long-term trends or average values.

The course of economic fluctuations on real estate market can vary depending on specific segments of this market. These fluctuations are often of national range conditioned by changing economic situation of the country. Taking into account a specific character of property - immobility - economic changes on real estate market are, first of all, of regional and local range. It means that even if the whole economy growths, one region or town can go

\footnotetext{
${ }^{1}$ On account of difficulties to assess the value of demand or supply, prices on real estate market are taken into consideration in most researches.
} 
through stagnation and vice versa. Local real estate market can develop even if the whole economy decreases.

As for the source of origin economic fluctuations on real estate market can be divided into [Dehesh, 1997]:

- exogenous economic fluctuations conditioned by external factors such as, for example, changing of percentage rates or changing of income level;

- endogenous economic fluctuations conditioned by internal factors such as delays in reactions of supply to market changes.

Real estate cycles are partly due to imperfection of this market. Delays can be probably the most important factors. Generally, the following delays are singled out:

- Delay being a result of price mechanism. Unexpected growth of demand meets a specific supply that is constant in short period of time. Market reaction to achieve short-term balance directs to price adjustment.

- Decision-making delay. It is necessary to take into consideration a number of conditions (legal, technical, economical) to prepare and to select a developer's project. Within the process of taking an investment decisions various factors of mutual connections should be taken into account and that makes the whole decision making process more complicated and difficult.

- Constructional delay. At the moment when investment decision is definitely made, the project has to be approved and the contract with Construction Company has to be signed.

Medium-term external influences to real estate cycles are strictly connected with an economic growth of the country or local market. They consist of changes of main economic factors such as inflation, percentage rates, GDP. Long-term influences are not of a sudden shock character, but are manifested in form of structural change. Examples of structural changes can be [Rottke, Wernecke, 2003]:

- political shock (establishing of the European Union),

- economic change of economies' structures (globalization),

- change in surface-time dimension (new communication technologies),

- growing ecological consciousness (new forms of spatial planning).

Cyclic development of residential markets creates some economic and political implications. These cycles are considered not to be eliminated, but knowledge of reasons and results of these cycles can limit some of their indications [Kucharska-Stasiak, 2006]. Researches regarding fluctuations on real estate market can be divided into researches on national, regional and local markets.

\section{Review of price cycles on real estate market in chosen OECD countries in 1970-2004}

In a straight majority of OECD countries real property prices were steadily increasing as from the middle of 1990. Graphs 1,2, 3 and 4 present development of indexes of real property prices of eighteen OECD countries in 1975-2004. These selected countries had been classified due to level of an increase or decrease of property prices after 1995 [Girouard, Kennedy, Noord, Andre, 2006]. The first group consists of countries in which real growth of property prices amounted to more than 100 per cent. The second group consists of countries in which real growth of property prices amounted to $60-100$ per cent. The third group consists of countries in which this growth amounted to 60 per cent. The fourth group consists of countries in which real property prices decreased. 


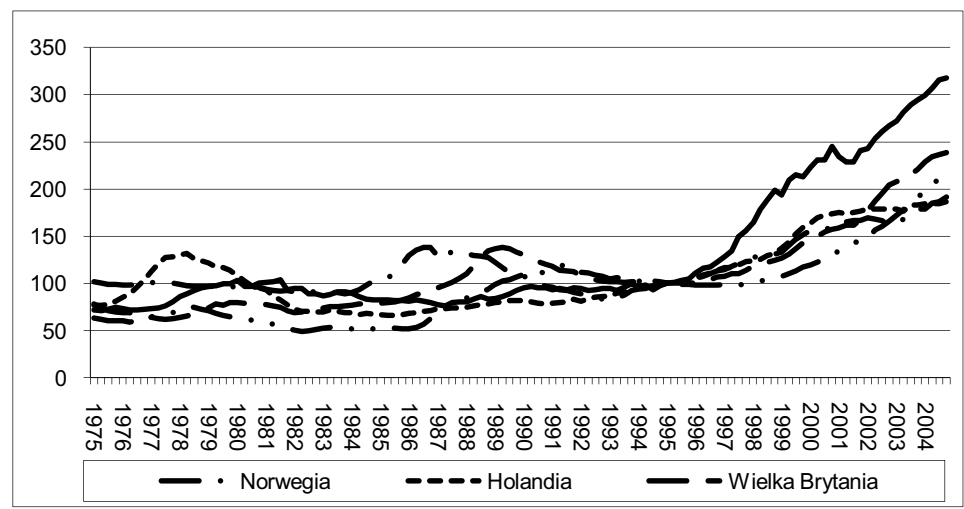

Graph 1. Real house price indexes in Spain, the Netherlands, Ireland, Norway and Great Britain in 1975-2004 ( I Q. $1995=100$ )

Source: N. Girouard, M. Kennedy, P. van den Noord, Ch. André, Recent House Price Developments: the Role of Fundamentals, Economics Department Working Papers No. 475, 2006 , p. 5.

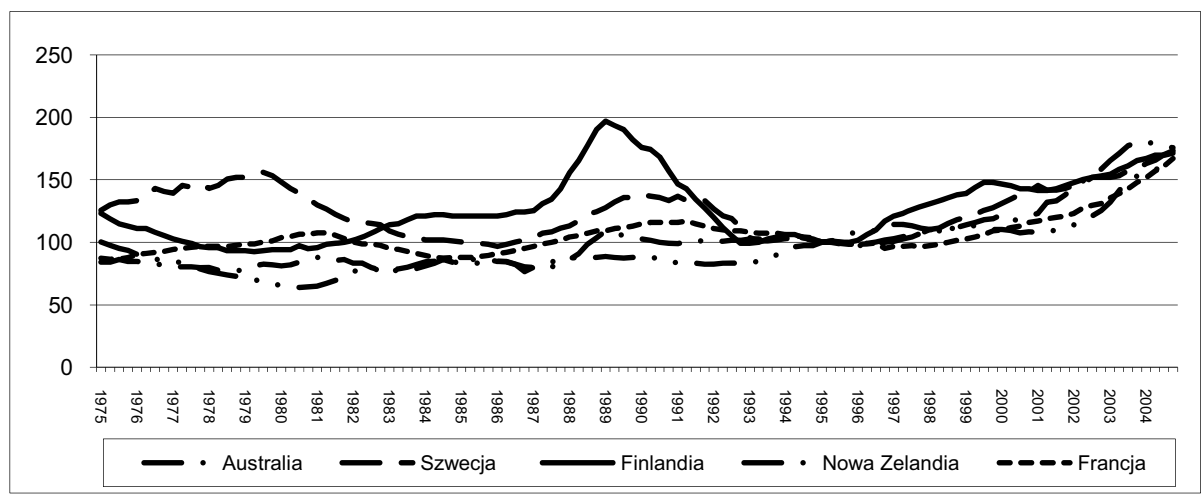

Graph 2. Real house price indexes in Australia, Sweden, Finland, New Zealand and France in 1975-2004 ( I Q. $1995=100$ )

Source: as graph 1. 


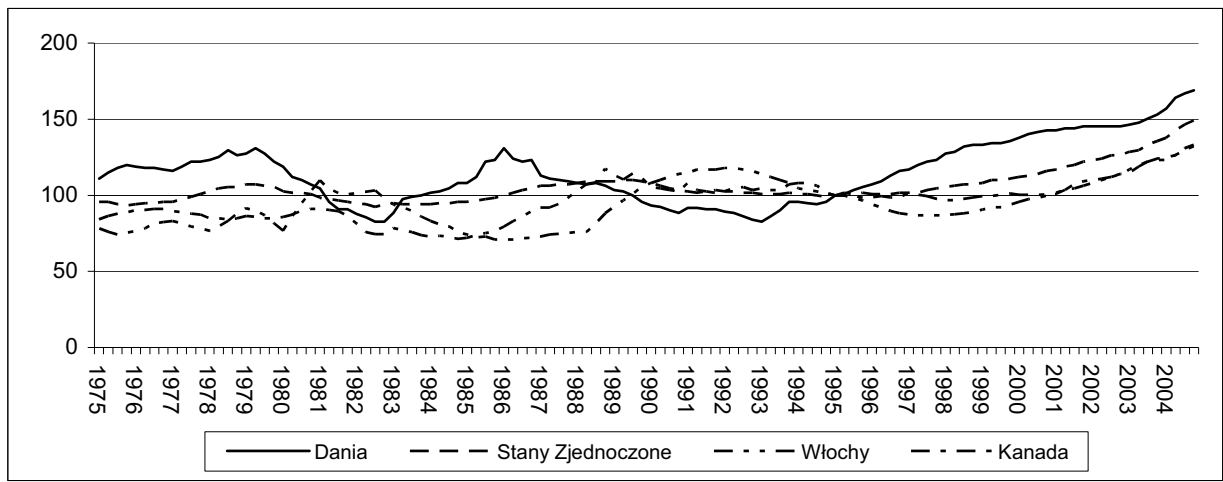

Graph 3. Real house price indexes in in Denmark, Canada, USA and Italy in 1975-2004 (I Q. $1995=100)$

Source: as graph 1.

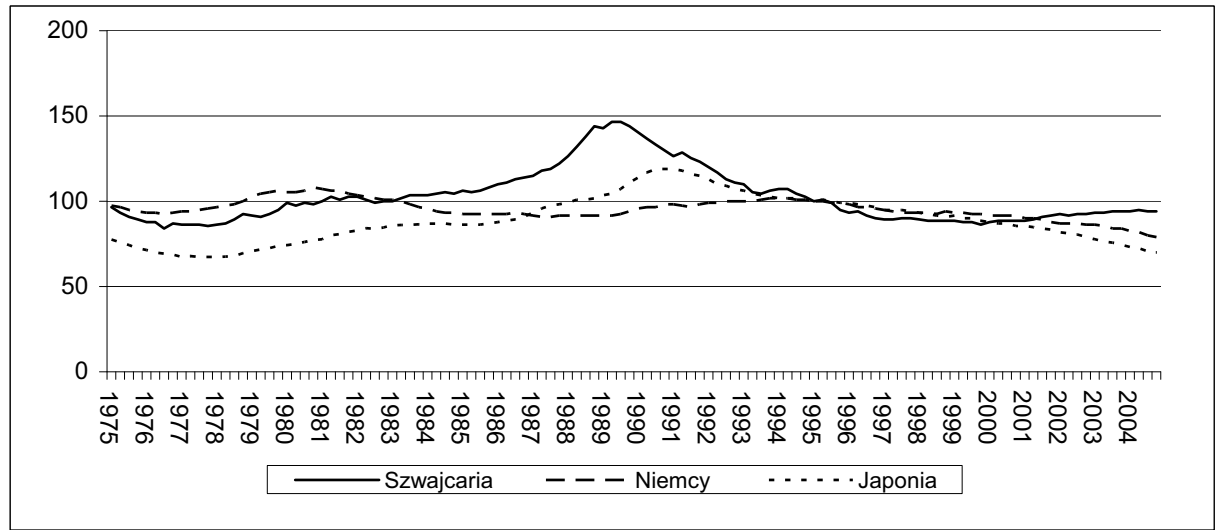

Graph 4. Real house price indexes in Japan, Germany and Switzerland in 1975-2004 (I Q. $1995=100)$

Source: as graph 1.

The highest, more than 200 per cent increase of real house prices, took place in Ireland. In Great Britain, Spain, the Netherlands and Norway prices increased less dynamic; they grew, however, more than 100 per cent. Australia, Sweden, Finland, New Zealand and France belong to the second group of countries in which real property prices increased more than 60 per cent in 1995-2005. In Denmark, USA, Italy and Canada real property prices increased around 60 per cent. The fourth group build countries in which real property prices decreased in 1995-2005. This tendency took place on real estate market of Switzerland, Germany and Japan.

Although the presented indexes of real property prices have been constructed basing on various data and various methods that could have an influence to accuracy of drawn conclusions, N. Girouard and others identified price cycles on real estate market in analysed countries in 1902004. According to their approach to the subject, single cycle consists of an increasing phase (positive price growth) and a decreasing phase (negative price growth). To avoid false cycles they assumed that minimum length of each phase has to be more than six 
quarters. Tables 1 and 2 present characteristics of increasing and decreasing phases of property prices' cycles in analysed countries in 1970-2004.

Table 1. Characteristics of increasing phases of real house prices' cycles in chosen OECD countries in 1970-2004

\begin{tabular}{|c|c|c|c|c|c|c|}
\hline Country & $\begin{array}{c}\text { Number } \\
\text { of phases }\end{array}$ & $\begin{array}{c}\text { Average time } \\
\text { (in quarters) }\end{array}$ & $\begin{array}{c}\text { Average } \\
\text { price } \\
\text { change (in } \\
\mathbf{\%})\end{array}$ & $\begin{array}{c}\text { Max. time (in } \\
\text { quarters) }\end{array}$ & $\begin{array}{c}\text { Max. price } \\
\text { change (in \%) }\end{array}$ & $\begin{array}{c}\text { Number of } \\
\text { phases of } \\
\text { change } \\
\mathbf{1 5 \%}\end{array}$ \\
\hline USA & 3 & 17 & 15,3 & 23 & 17 & 1 \\
\hline Japan & 2 & 34,5 & 67 & 54 & 77,6 & 2 \\
\hline Germany & 3 & 21,3 & 12,1 & 27 & 15,7 & 1 \\
\hline France & 2 & 35,5 & 32,1 & 44 & 33 & 2 \\
\hline Italy & 2 & 34,5 & 81,9 & 44 & 98 & 2 \\
\hline Great Britain & 3 & 18,3 & 64,2 & 30 & 99,6 & 3 \\
\hline Australia & 6 & 14,3 & 31,6 & 32 & 84,7 & 3 \\
\hline Denmark & 2 & 25 & 44,3 & 37 & 56,6 & 2 \\
\hline Finland & 3 & 25,7 & 61,9 & 40 & 111,8 & 3 \\
\hline Ireland & 2 & 29 & 40,8 & 46 & 53,9 & 2 \\
\hline The Netherlands & 1 & 33 & 98,4 & 33 & 98,4 & 1 \\
\hline Norway & 2 & 14 & 33,7 & 16 & 56,3 & 1 \\
\hline Spain & 3 & 15 & 63,6 & 23 & 134,8 & 3 \\
\hline Sweden & 2 & 19 & 35,8 & 22 & 42,5 & 2 \\
\hline Switzerland & 3 & 28,3 & 40,2 & 53 & 73,5 & 2 \\
\hline Average & $\mathbf{2 , 7}$ & $\mathbf{2 2 , 7}$ & $\mathbf{4 5 , 6}$ & $\mathbf{3 2 , 7}$ & $\mathbf{6 7 , 6}$ & $\mathbf{2 , 1}$ \\
\hline
\end{tabular}

Source: N. Girouard, M. Kennedy, P. van den Noord, Ch. André, Recent House Price Developments: The Role of Fundamentals, Economics Department Working Papers No. 475, 2006, p. 7.

Table 2. Characteristics of increasing phases of real house prices' cycles in chosen OECD countries in 1970-2004

\begin{tabular}{|c|c|c|c|c|c|c|}
\hline Country & $\begin{array}{c}\text { Number } \\
\text { of phases }\end{array}$ & $\begin{array}{c}\text { Average time } \\
\text { (in quarters) }\end{array}$ & $\begin{array}{c}\text { Average } \\
\text { price } \\
\text { change (in } \\
\mathbf{\%} \text { ) }\end{array}$ & $\begin{array}{c}\text { Max. time } \\
\text { (in quarters) }\end{array}$ & $\begin{array}{c}\text { Max. price } \\
\text { change } \\
\text { (in \%) }\end{array}$ & $\begin{array}{c}\text { Number of } \\
\text { phases of } \\
\text { change } \\
>\mathbf{1 5 \%}\end{array}$ \\
\hline USA & 3 & 14,3 & $-9,9$ & 21 & $-13,9$ & 0 \\
\hline Japan & 1 & 15 & $-30,5$ & 15 & $-30,5$ & 1 \\
\hline Germany & 2 & 16,5 & $-10,7$ & 25 & $-15,3$ & 1 \\
\hline France & 2 & 18,5 & -18 & 23 & $-18,1$ & 2 \\
\hline Italy & 2 & 22 & $-30,6$ & 23 & $-35,3$ & 2 \\
\hline Great Britain & 3 & 16,3 & -25 & 25 & $-33,7$ & 2 \\
\hline Australia & 5 & 10 & $-10,1$ & 19 & $-14,7$ & 0 \\
\hline Denmark & 2 & 21,5 & $-36,2$ & 29 & $-36,8$ & 2 \\
\hline Finland & 3 & 14 & $-28,4$ & 19 & $-49,7$ & 2 \\
\hline Ireland & 2 & 16 & $-15,5$ & 23 & $-27,1$ & 1 \\
\hline The Netherlands & 1 & 29 & $-50,4$ & 29 & $-50,4$ & 1 \\
\hline Norway & 3 & 21,3 & $-19,8$ & 28 & $-40,6$ & 1 \\
\hline Spain & 3 & 19,3 & $-21,6$ & 31 & $-32,2$ & 2 \\
\hline Sweden & 3 & 22,3 & $-22,7$ & 26 & $-37,9$ & 2 \\
\hline Switzerland & 2 & 26,5 & $-34,8$ & 41 & $-40,7$ & 2 \\
\hline Average & $\mathbf{2 , 6}$ & $\mathbf{1 8 , 5}$ & $\mathbf{- 2 3 , 3}$ & $\mathbf{2 5 , 4}$ & $\mathbf{- 3 2 , 4}$ & $\mathbf{1 , 3}$ \\
\hline
\end{tabular}

Source: as Table 1. 
The Table 1 and 2 shows that an average length of price cycle on real estate market in this particular period of time was around ten years. In the course of increasing phase (around six years approximately), real property prices increased by ca. 45 per cent. Decreasing phase was relatively shorter (around five years approximately) and real property prices decreased by ca. 25 per cent. To work on the assumption that significant increase or decrease of real prices is 15 per cent minimum, phases of sudden increases and decreases of prices can be determined. It seems to be interesting that in all analysed countries it was at least one period in which real property prices increased by more than 15 per cent, but significant price decrease had not take place in every country in thirty-year period (USA and Australia).

Analysis of fluctuations of property prices in various countries shows that these cycles vary not only with duration of time but also with fluctuation's amplitude. The heart of the matter lies mainly with economic and demographic factors, as well as with the structure of real estate market specific for every country.

Main reason why the interest in real estate market constantly increases is a significant price growth (real price growth) in the beginning of 21 st century. Moreover, in this period of time property prices started to behave differently in relation to GDP. In OECD countries in 1970-2000 changes of property prices aimed to the GDP changes, but after 2000 this trend has been changed and prices became anti-cyclic.

\section{Fluctuations of house prices in Poland - the case of Poznań in 1996-II Q. 2009}

To estimate property price cycles in Poznań it has been assumed that one cycle consists of an increasing phase (positive price growth) and a decreasing phase (negative price growth). To avoid false cycles minimum length of each phase has to be more than six quarters.

An index of real flats' prices in Poznań in 1996 - II Q. 2009 (after seasonal adjustment ARIMA X-12) has been used to identify fluctuations of real estate prices. This index has been built basing on offers' data (the size of test after methodological works - incomplete or repeated offers had been deleted - amounted to 97,000 sales offers in multifamily buildings) and average method (location and construction period were taken into consideration). Graph 5 shows index of real flats' prices in Poznań in 1996 - II Q. 2009.

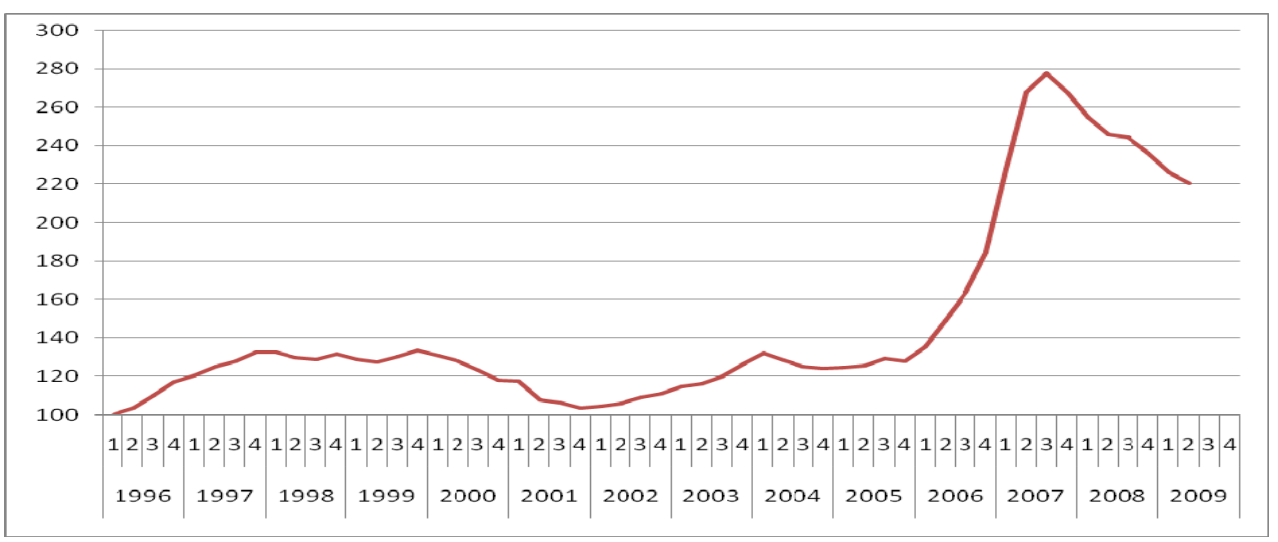

Graph 5. Index of real flats' prices in Poznań in 1996-II Q. 2009r.

Source: own researches. 
In 1996-2009 the Poznań real estate market presented one full cycle of 31 quarters from I Q. 2000 to III Q. 2007. The beginning of increasing phase which ends in IV Q. 1999, cannot be determined because we don't know fluctuations of price of one square meter of flat before 1996 and in period of I Q. 1996 - IV Q. 1999 any turning point was observed. It can be only stated that this increasing phase was 16 quarters long. In IV quarter of 2007 the next seven quarters decreasing phase begun and it ends in II quarter of 2009.

Real prices of flats in Poznań in 1996 - II Q. 2009 increased by ca. 120 per cent. Increasing and decreasing phases of index are noticeable. In the first decreasing phase prices of flats decreased by 21 per cent. Next price increase lasted for about six years. Real prices of flats increased by ca. 165 per cent in this period of time. Decreasing phase that started in IV quarter of 2007 and lasted till II quarter of 2009 made price declining by ca. 20 per cent.

\section{Conclusion}

The problem of price cycles on residential market has been attempted in this paper. There were presented main theoretical assumptions, price cycles in the chosen OECD countries and trial to identify price fluctuations of residential market in Poznań. In $1996-$ 2009 one full cycle has been identified; it lasted quite 8 years, including 2 years of decreasing phase and 6 years of increasing phase. To compare the length of this cycle to price cycles in OECD countries, it was close to an average period. It has to be stated that decreasing phases on real estate market in Poznań took place in the period of economic slump in Poland. This is identical to other researches. They show that dwelling's price cycle responds to key economic elements but it is not a simple reflection of the business cycle of the country.

\section{Summary}

The market of separate goods, as well as the whole economy, is subject to economic fluctuations. All markets fluctuate, including the real estate market. The problem of price cycles on residential market has been attempted in this paper. There were presented main theoretical assumptions, price cycles in the chosen OECD countries and trial to identify price fluctuations on real estate market in Poznań. In 1996 - 2009 one full cycle has been identified; it lasted quite 8 years, including 2 years of decreasing phase and 6 years of increasing phase. To compare the length of this cycle to price cycles in OECD countries, it was close to an average period. It has to be stated that decreasing phases on real estate market in Poznań took place in the period of economic slump in Poland. This is identical to other researches. They show that real estate cycle responds to key economic elements but it is not a simple reflection of the business cycle of the country.

\section{References}

1. Baum A. (2001), Evidence of Cycles In European Commercial Real Estate Markets and Some Hypoteses, w S. Brown, C. Liu, A Global Perspective on Real Estate Cycles, Massachusetts: Kluwer.

2. Dehesh A., C. Pugh (1997), Real Estate Cycle, Internationalised Transmission Mechanism and the Japanese Bubble Economy, RICS Research Paper Series 1997, vol. 2 , No. 6.

3. Gawron H. (2006), Opłacalność inwestowania na rynku nieruchomości, Wyd. AE w Poznaniu, Poznań. 
4. Girouard N., M. Kennedy, P. van den Noord, Ch. André (2006), Recent House Price Developments: The Role of Fundamentals, Economics Department Working Papers 2006, No. 475.

5. Key T., B.Macgregor, N.Nanthakumaran, F. Zarkesh (1994), Understanding the Property Cycle, RICS, London.

6. Kucharska-Stasiak E. (2006), Nieruchomość w gospodarce rynkowej, Wyd. Naukowe PWN, Warszawa.

7. Rottke N., M. Wernecke, A. Schwartz (2003), Real Estate Cycles in Germany Causes, Empirical Analysis and Recommendations for the Management Decisions, Journal of Real Estate Literature 2003, vol. 11, No. 3.

8. Trojanek R. (2008), Wahania cen na rynku mieszkaniowym, Wyd. AE w Poznaniu, Poznań. 